\title{
China's Practice in Treaty Reservations since 1949: Legal and Policy Evaluation
}

\author{
Yong Wang*
}

Since its founding in 1949, the People's Republic of China has acceded to more than 300 multilateral treaties. Among them, China made reservations to 83 treaties, accounting for nearly 27.7 percent of the total. Evidently, for China, formulating reservations to multilateral treaties is an issue of vital importance in the process of concluding and executing multilateral treaties. This paper examines the three main reasons why China inclines to formulate reservations to the treaties, then argues that the reservations formulated by China, whether in procedure or in substance, are not only in full conformity with the 1969 Vienna Convention on the Law of Treaties, but also full of Chinese characteristics. This paper also analyzes several specific reservations that China shall withdraw, and addresses the limitations of China's existing treaty reservation system. Accordingly, this paper concludes that the Chinese government should improve and perfect its treaty reservation system with some suggestions.

\section{Keywords}

Reservations to Treaties, Multilateral Treaties, Vienna Convention on the Law of Treaties, China's Practice

* Professor of International Law at East China University of Political Science and Law (ECUPL), China. LL.B. /LL.M. /Ph.D. (ECUPL). ORCID: http://orcid.org/0000-0002-4558-3663. This research is supported by 'Shuguang Program' from Shanghai Education Development Foundation and Shanghai Municipal Education Commission. Much gratitude is extended to Prof. Eric Y. J. Lee for his insightful advice. The author may be contacted at: yongyongsh@163.com / Address: International Law School, East China University of Political Science and Law, No. 1575 Wanghangdu Road, Shanghai, 200042, P.R. China. 


\section{Introduction}

Since its founding in 1949, the People's Republic of China ("PRC") ${ }^{1}$ has acceded to more than 300 multilateral treaties. Among them, it formulated reservations to 83 treaties, accounting for nearly 27.7 percent of the total. ${ }^{2}$ In addition, China made a series of reservations and declarations on July 1, 1997 when the United Kingdom transferred the sovereignty of Hong Kong back to China for the continuing application of 62 multilateral treaties in Hong Kong. Formulating reservations to treaties by China is an issue of vital importance in the process of the concluding and executing the treaties for nearly 70 years. ${ }^{3}$ In this context, it is not only essential to critically review the long-history of China's practice in treaty reservation, but also worthwhile to identify the problems from the longstanding practice, and ultimately to improve and renovate the present treaty reservation system of China.

The primary purpose of this research is to improve and perfect the present treaty reservation system of China. This paper is composed of seven parts including an Introduction and Conclusion. Part two will review the main reason why China formulates the reservation to treaties. Part three will discuss procedural issues concerning China's practice in reservation. Part four will examine China's reservations to treaties. Part five will analyze two specific reservations that China should withdraw. Part six will suggest the renovations of treaty reservation system of China.

\section{Why China Formulates Reservations to Treaties?: Three Main Reasons}

There are three main reasons why China formulates reservations to the treaties. The first one is political reasons. China formulated a reservation to provisions concerning nuncios and the representative of the Holy See in Articles 14 and 16 of the 1961

\footnotetext{
Hereinafter referred to as 'China.'

2 In this paper, the statistics of reservations to multilateral treaties of China are cited from the series of TREATY Compilations of the People’s Republic of China [中国人民共和国条约集] <available only in Chinese>. This series has been edited by the Department of Treaty and Law of the PRC Ministry of Foreign Affairs almost every year. Only those treaties with binding forces, acceded to by China could be selected into the Compilations. As of May 10, 2017, the 58th volume was published.

3 In this paper, "reservations to treaties" denote those reservations to multilateral treaties.
} 
Vienna Convention on Diplomatic Relations. The reason for this reservation is that China has not yet recognized the Holy See as an independent sovereign State. Accordingly, China holds the opinion that the representatives of the Holy See should not possess the status of envoys. ${ }^{4}$ In addition, On September 5, 1988, the Standing Committee of the National People's Congress of China decided to approve the Second and Third Protocols of the South Pacific Nuclear Free Zone Treaty signed by the representative of the Chinese government on February 10, 1987. This also reaffirmed the Statement made at the time of signing the above protocols. The Statement reads as follows:

The signing of the two Protocols does not mean that China has changed the position towards the Treaty on the Non-Proliferation of Nuclear Weapons and the Partial Nuclear Test Ban Treaty. If other nuclear States or States Parties of the above Treaties should seriously violate the treaties, which would change the status of nuclearfree zones and endanger China's security interests, China would retain the right to reconsider the obligations. ${ }^{5}$

The Chinese government continuously advocates the complete prohibition and thorough destruction of nuclear weapons. It has repeatedly stated that "at no time and under no circumstances will China be the first to use nuclear weapons." However, China may use nuclear weapons in self-defense. The reservation is just a reflection of China's above political positions.

The second one is legal reasons. China formulated a written reservation to the United Nations Convention on Contracts for the International Sale of Goods, because China's domestic law did not recognize the effectiveness of oral contracts then. ${ }^{7}$ In

4 The Holy See has been keeping diplomatic relationship with the "Republic of China" since 1942.Until now, meanwhile, China has not yet recognized the Holy See as an independent sovereign State, either. For details, see The Data Table of Establishing Diplomatic Relations between China and Other Countries [中华人民共和国与各国建立外交关系日期 简表], available at http://www.fmprc.gov.cn/web/ziliao_674904/2193_674977 (last visited on Oct. 3, 2017).

5 See Decision of the Standing Committee of the National People's Congress on Ratification of Protocols Nos. 2 \& 3 of the South Pacific Nuclear Free Zone Treaty [全国人民代表大会常务委员会关于批准《南太平洋无核区条约》第 二号和第三号议定书的决定], available at http://www.npc.gov.cn/wxzl/gongbao/2000-12/16/content_5002162.htm (last visited on Oct. 3, 2017).

6 See State report on the Implementation of the Treaty on the Nonproliferation of Nuclear weapons of China [关于中华 人民共和国履行《不扩散核武器条约》情况的国家报告], available at http://www.fmprc.gov.cn/123/wjb/zzjg/jks/ jkcjxb/d1/t267558.htm (last visited on Oct. 3, 2017).

7 Law of the People's Republic of China on Economic Contracts concerning Foreign Interests, art. 7(1). It reads: "A contract shall be formed as soon as the parties to it have reached a written agreement on the terms and have signed the contract. If an agreement is reached by means of letters, telegrams or telex and one party requests a signed letter of confirmation, the contract shall be formed only after the letter of confirmation is signed. Contracts which are subject to the approval of the State, as provided for by the laws or administrative regulations of the People's Republic of China, 
addition, when the Standing Committee of China's Tenth National People's Congress decided to join the WIPO Performances and Phonograms Treaty on December 29, 2006, China made a statement that it should not be bound by Article 15, Paragraph $1^{8}$ of the WIPO Performances and Phonograms Treaty. ${ }^{9}$ The 2001 revision of China's Copyright Law provides that China adopted the statutory licensing system to regulate broadcasting recording products of radio and television stations. ${ }^{10}$

In view of the relatively tense situation of China's radio and television funds, playing published recording products, the payment objects of radio and television stations are limited to the copyright owners, while the performers and the producers of the recordings have no such rights. Because of the difference between Article 15, Paragraph 1 of China's Copyright Law and the WIPO Performances and Phonograms Treaty, China made the above reservation. Another example worth noting is that the Chinese government decided to accede to the New York Convention on the Recognition and Enforcement of Foreign Arbitral Awards on December 2, 1986. It issued a statement which reads:

The People's Republic of China applies the Convention to the arbitral awards of recognition and enforcement made in the territory of another State Party only on a reciprocal basis. ${ }^{11}$

China formulated such a reservation mainly because China's Civil Procedure Law has adopted the principle of reciprocity in international judicial assistance. ${ }^{12}$

The third is a mixture of political and legal reasons. On July 3, 1997, China

shall be formed only after such approval is granted."

8 WIPO Performance and Phonograms Treaty, art. 15(1). It reads: "Performers and producers of phonograms shall enjoy the right to a single equitable remuneration for the direct or indirect use of phonograms published for commercial purposes for broadcasting or for any communication to the public." See WPPT Authentic Text, available at http:// www.wipo.int/wipolex/en/treaties/text.jsp?file_id=295578 (last visited on Oct. 3, 2017).

9 Decision of the Standing Committee of the National People's Congress on Accession to the WIPO Performances and Phonograms Treaty, Gazette of the State Council of the People's Republic of China, 2007, No.5, at 11. <available only in Chinese>

10 The Copyright Law (2001), art. 43. It reads: "A radio station or television station may broadcast, for noncommercial purposes ,a published sound recording without seeking permission from, or paying remuneration to, the copyright owner, performer and producer of the sound recording." < available only in Chinese>

11 Decision of the Standing Committee of the National People's Congress on Accession to the New York Convention on the Recognition and Enforcement of Foreign Arbitral Awards, Gazette of the State Council of the People's Republic of China, 1987, No.7, at 243. <available only in Chinese>

12 PRC Civil Procedure Law (Trial) (1982), art. 202. It reads : "In accordance with the international treaties concluded or acceded to by the People s Republic of China or on the principle of reciprocity, the people s courts of China and foreign courts may request each other's assistance in the service of legal documents, in investigation and collection of evidence or in other litigation actions." < available only in Chinese $>$ 
decided to accede to the Convention on the Taking of Civil or Commercial Evidence from Abroad. In this case, the Chinese government also formulated a reservation on its application to the Hong Kong Special Administrative Region (“HKSAR”):

As to Article 16, Foreign ministers or consular representatives of other Contracting States are not allowed to obtain evidence from nationals of the People's Republic of China or third States in the HKSAR. ${ }^{13}$

According to China's Civil Procedure Law, China has always regarded the secret investigation in the international judicial assistance as illegal. Hence, without an approval of China's authorities, any foreign authority or individual shall not investigate or collect evidence from Chinese citizens within Chinese territory. ${ }^{14}$ Meanwhile, it is 'politically' conceivable that China needs to safeguard its territorial sovereignty and the personal safety of its citizens.

Another example is China's ratification of the 1989 UN Convention on the Rights of the Child on December 29, 1991. Then, China stated that it would fulfill the obligations under Article 6 of the Convention in accordance with Article 25 of the PRC Constitution on family planning, as well as Article 2 of the PRC Law of on the Protection of Minors. ${ }^{15}$ The PRC Constitution stipulates that Chinese citizens shall implement family planning obligations. ${ }^{16}$ This is based on the political need for China to control population growth with balanced economic and social development.

Furthermore, on February 28, 2001, China ratified the International Covenant on Economic, Social and Cultural Rights, signed on October 27, 1997. Upon the ratification, China stated:

Article 8(1)(a) of the International Covenant on Economic, Social and Cultural Rights shall be implemented in according with the Constitution of the People's Republic

13 Decision of the Standing Committee of the National People's Congress on Accession to the Convention on the Taking of Evidence Abroad in Civil or Commercial Matters, Gazette of the State Council of the People's Republic of China, 1997, No. 23, at 1032.<available only in Chinese>

14 PRC Civil Procedure Law (1991), art. 263(3). It reads: "Except for the circumstances prescribed in the preceding paragraph, no foreign organization or individual may, without the consent of the competent authorities of the People s Republic of China, serve documents or carry out investigation and collection of evidence within the territory of the People's Republic of China." <available only in Chinese>

15 Decision of the Standing Committee of the National People's Congress on Ratification of the Convention on the Rights of the Child, Gazette of the State Council of the People's Republic of China, 1991, No. 46, at 1601. <available only in Chinese>

16 PRC CONST. art. 25. It reads: "The State promotes family planning so that population growth may fit the plans for economic and social development.” See The Constitution of the People’s Republic of China [中华人民共和国宪法], available at http://en.people.cn/constitution/constitution.html (last visited on Oct. 3, 2017). 
of China, Law of the People's Republic of China on Trade Unions, Labor Law of the People's Republic of China and any other relevant provisions of the law. ${ }^{17}$

China made the above reservations for its Constitution. The Labor Union Law and the Labor Law have not yet given Chinese workers the right to freely organize trade unions without any legal restrictions. Chinese people shall adhere to the political leadership of the Communist Party to the trade unions.

\section{The Procedural Issues concerning Chinese Practice in Formulating Reservations to Treaties}

\section{A. Upon Which Occasions Reservations May Be Formulated?}

Regarding China's practices on the treaty reservation, there are three points worth noting. First, China has demonstrated not only its firm attitude of abiding by the treaties, but also prudent approach of formulating reservations to other parties. The reservations to treaties were the result of China's careful considerations after scrutinizing the treaties, which would effectively prevent possible mistakes in the conclusion of the treaties.

Second, China has formulated the reservations to the treaties in full compliance with the requirements of international law. Article 2 of the Vienna Convention of the Law of Treaties ("VCLT") provides:

Reservation means a unilateral statement, however phrased or named, made by a State, when signing, ratifying, accepting, approving or acceding to a treaty, whereby it purports to exclude or to modify the legal effect of certain provisions of the treaty in their application to that State. ${ }^{18}$

The VCLT ignores that the reservations can also be formulated by a State when making a notification of succession to a treaty or formally confirming a treaty, besides from signing, ratifying, accepting, approving or acceding to a treaty.

At present, the most comprehensive definition of reservation is stipulated in the International Law Commission's Guide to Practice on Reservations to Treaties

\footnotetext{
17 Decision of the Standing Committee of the National People's Congress on Ratification of the International Covenant on Economic, Social and Cultural Rights, Gazette of the Standing Committee of the National People's Congress of the People's Republic of China, 2001, No.12, at 52. <available only in Chinese>

18 VCLT art. 2, 94.
} 
(“GPRT”). ${ }^{19}$ It provides:

\begin{abstract}
"Reservation" means a unilateral statement, however phrased or named, made by a State or an international organization when signing, ratifying, formally confirming, accepting, approving or acceding to a treaty or by a State when making a notification of succession to a treaty, whereby the State or organization purports to exclude or to modify the legal effect of certain provisions of the treaty in their application to that State or to that international organization. ${ }^{20}$
\end{abstract}

The definition in GPRT reflects the existing customary international law, having a general binding force to all the States. As the special rapporteur noted, the contemporary doctrines almost unanimously uphold the definition, which has become the authoritative definition and constitutes an inevitable starting point for any thought on reservations. ${ }^{21}$ State parties may even put forward 'outdated reservations' in addition to the above-mentioned occasions, provided that other States Parties have no objections. ${ }^{22}$ This may demonstrate the legitimacy of the reservations made by China.

Last, on the eve of the transfer of sovereignty of Hong Kong to China in 1997, to solve the issues arising from the application of treaties to the HKSAR, the Chinese government specifically made declarations and reservations to 62 multilateral treaties for their continued application in the HKSAR, to 24 of which both China and Hong Kong are States Parties. As the HKSAR government is essentially a local government of China, the reservations to the treaties applied in the HKSAR are sovereign acts of China under international law. Furthermore, China's territory expanded when Hong Kong was 'returned.' Thus, it is reasonable to formulate reservations to the treaties on this occasion, as GPRT provides:

A unilateral statement by which a State, when extending the applicable of a treaty, purports to exclude or to modify the legal effect of certain provisions of the treaty in relation to that territory constitutes a reservation. ${ }^{23}$

19 U.N. GAOR, 66th Sess., Supp. No 10, U.N. Doc. A/66/10 (Apr. 26 - June \& July 4-Aug. 12 2011), available at http:// legal.un.org/ilc/texts/instruments/english/draft_articles/1_8_2011.pdf(last visited on Oct. 3, 2017).

20 GPRT 1.1

21 See Report of the International Law Commission on the work of its fiftieth session, 53 U.N. GAOR, Supp. No 10, reprinted in [1998] II(2) Y.B. Int'l L. Comm'n, U.N. Doc. A/53/10 (Apr. 20 - June 12 \& July 27-Aug. 14 1998), available at http://legal.un.org/ilc/documentation/english/reports/a_53_10.pdf (last visited on Oct. 3, 2017).

22 C. Walter, Reservations, in Vienna Convention on the Law of Treaties, A Commentary 257 (O. Dörr \& K. Schmalenbach eds., 2012).

23 GPRT 1.1.4. 
The status upon the occasions when China formulated reservations to the treaties can be illustrated in Table 1.

Table 1: The Occasions of China's Treaty Reservations ${ }^{24}$

\begin{tabular}{|c|c|c|}
\hline Occasion of formulating reservations & Number of treaties & $\begin{array}{c}\text { Percentage } \\
\text { in total }\end{array}$ \\
\hline Upon accession & 45 & $54.2 \%$ \\
\hline Upon signature & 5 & $6 \%$ \\
\hline Upon making notifications of succession & 6 & $7.2 \%$ \\
\hline Upon acceptance & 3 & $3.6 \%$ \\
\hline Upon ratification & 18 & $21.7 \%$ \\
\hline Upon approval & 4 & $4.8 \%$ \\
\hline \multirow{2}{*}{ on July 1, 1997 } & 2 & $2.4 \%$ \\
\hline & 22 (Second Time Reservations) & $/$ \\
\hline
\end{tabular}

\section{B. Who Formulates Reservations to the Treaties in China?}

In China, treaty reservation is formulated by the Standing Committee of the National People's Congress ("SCNPC"), the State Council, and the Ministry of Foreign Affairs. The SCNPC is the main organ competent to render the decisions to formulate reservations. The Committee has made the final reservation decisions of 67 treaties. The State Council can also render the decisions to formulate reservations. The State Council has decided the final reservations to nine treaties. The Ministry of Foreign Affairs has also made reservation decisions to 11 treaties, including 4 reservation decisions that were confirmed by the SCNPC. ${ }^{25}$

The SCNPC is the main authority to render the decisions to formulate reservations for the following reasons. First, the SCNPC is precisely entitled to ratify or accede to treaties under Article 67 of the PRC Constitution ${ }^{26}$ and Article 7 of the PRC Procedural Law on Conclusion of Treaties. ${ }^{27}$

24 Compiled by the author.

25 The 4 reservations to the 4 treaties are as follows: 1 . The Convention on the Elimination of All Forms of Discrimination against Women; 2. The Convention against Torture and Other Cruel, Inhuman or Degrading Treatment or Punishment; 3. Additional Protocols to the South Pacific Nuclear Free Zone Treaty second and third; and 4. The Convention for the Suppression of Unlawful Acts against the Safety of Maritime Navigation.

26 PRC CONST. art. 67, 14. It reads: "The SCNPC is the organ that decides on the ratification or abrogation of treaties and important agreements concluded with foreign States."

27 PRC Procedural Law on Conclusion of Treaties, art. 7(1). It reads: "The ratification of treaties and important 
Second, the SCNPC can spend enough time for in-depth study of the treaties. Because the time from the negotiation to the signing of the treaties is relatively short, it is more appropriate for the SCNPC to formulate reservations to the treaties when ratifying or acceding to them. This practice would demonstrate China's cautious attitudes of formulating reservations.

Third, pursuant to Article 23 of the $\mathrm{VCLT}^{28}$ reservation shall be considered as having been made on the date of its confirmation. Although some reservations have been formulated at the time of signature, if these treaties are acceded, they still need to be approved by the SCNPC to confirm previous reservations. When ratifying the Convention on the Elimination of All Forms of Discrimination against Women, the Convention against Torture and Other Cruel, the Inhuman or Degrading Treatment or Punishment, Convention for the Suppression of Unlawful Acts against the Safety of Maritime Navigation, and in the context of the Second and Third Additional Protocols to the South Pacific Nuclear-Free Zone Treaty, e.g., the SCNPC confirmed the reservations formulated by the Ministry of Foreign Affairs when the representatives were signing those treaties.

\section{Other Procedural Questions}

There are further procedural questions to be examined. First, the phrasing of the reservations adopted by China. The Chinese Government has adopted the phrase "make a declaration" mainly to formulate a reservation, sometimes followed by the phrase of "make a reservation," but rarely referred to "make a decision."

Second, China has made all the reservations in written forms. These include instruments of accession, ratification, approval, notification, etc. Table 2 shows some examples of the instruments for reservation of China.

agreements shall be decided upon by the Standing Committee of the National People's Congress. The treaties and important agreements referred to in the preceding paragraph are as follows: 1. Treaties of friendship and cooperation, treaties of peace and other treaties of a political nature; 2 . Treaties and agreements concerning territory and delimitation of boundary lines; 3 . Treaties and agreements relating to judicial assistance and extradition; 4 . Treaties and agreements which contain stipulations inconsistent with the laws of the People's Republic of China; 5. Treaties and agreements which are subject to ratification as agreed by the contracting parties; and 6. Other treaties and agreements subject to ratification." See The Procedural Law of the People's Republic of China on Conclusion Treaties (English-Chinese) [中 华人民共和国缔结条约程序法-英汉对照], available at http://www.chinalawedu.com/new/23223a23228a2010/201 01216shangf153526.shtml (last visited on Oct. 3, 2017).

28 VCLT art. 23 2. It reads: "If formulated when signing the treaty subject to ratification, acceptance or approval, a reservation must be formally confirmed by the reserving State when expressing its consent to be bound by the treaty." 
Table 2: China's Treaty Reservation Form (Examples of Instruments)

\begin{tabular}{|l|c|}
\hline \multicolumn{1}{|c|}{ Treaty } & Instrument for Reservation \\
\hline Vienna Convention on Diplomatic Relations & Accession \\
\hline 1949 Geneva Conventions & Ratifications \\
\hline 2006 International Tropical Timber Agreement & Approval \\
\hline International Monetary Fund Agreement & Notification \\
\hline
\end{tabular}

Among them, accession is the main form of China's reservations, as most of the reservations are formulated when China was acceding to the treaties, whose contents will be added into the instruments of accessions.

Third, reservations are also withdrawn in a written form. Until now, the Chinese government has withdrew only two reservations. One was the withdrawal of reservation to Articles 37 (2), (3) and (4) of the Vienna Convention on Diplomatic Relations when it acceded to the Convention on September 15, 1980. ${ }^{29}$ This withdrawal was concerned with certain privileges and immunities of the administrative and technical staff and their families, together with service staff and private servants of members of the mission. The other was the formal notification by the Chinese government to the UN Secretary-General on January 16, 2013 to withdraw the reservation "not to be bound by the provisions of Article 11 of the Convention and the provisions relating to Article 11 of the United Nations Convention on Contracts for the International Sale of Goods." ${ }^{30}$ The statement of withdrawal formally entered into force on August 1, 2013. In both cases, the Chinese government issued notification of withdrawal in a written form.

In toto, China's formulation of reservations to treaties has been in line with Article 23 of the VCLT, which is indispensable to determine whether the reservations are valid or not. ${ }^{31}$

29 The Chinese government withdrew the reservations to Articles 37 (2), (3) \& (4) of the Vienna Convention on Diplomatic Relations (in note 18), available at https://treaties.un.org/pages/ViewDetails.aspx?src=TREATY\&mtdsg no=III-3\&chapter=3\&clang=_en\#2 (last visited on Oct. 3, 2017).

30 UNIS, China Withdraws "Written Form" Declaration under the United Nations Convention on Contracts for the International Sale of Goods (CISG), Press Release, Jan. 18, 2013, available at http://www.unis.unvienna.org/unis/ pressrels/2013/unisl180.html (last visited on Oct. 3, 2017).

31 A. Aust, Modern Treaty Law and Practice 137 (3d ed. 2013). 


\section{China's Reservations to Treaties}

\section{A. The Reservations to International Dispute Settlement Clauses}

This reservation to international dispute settlement clauses are related to the International Court of Justice ("ICJ") or international arbitration courts. China has formulated the reservations to 26 treaties so far

Reservations to international dispute settlement clauses can be categorized into as follows. First, China formulates reservations if the clauses stipulate the ICJ as the only option for dispute settlement. China made such reservations to nine treaties. On November 26, 1981, the SCNPC stated that China would make a reservation to Article 22 of the 1966 International Convention on the Elimination of All Forms of Racial Discrimination and should not be bound by this Article. ${ }^{32}$

Second, China formulates reservations if the clauses lay down various international arbitration as the only institution for dispute settlement. China has made such reservations to three treaties. When the SCNPC was ratifying the Convention on the Prevention of Marine Pollution by Dumping of Wastes and Other Matters on June 29, 2006, e.g., it made a reservation to Article 16, paragraphs 2 and 5 of the Protocol to the Convention because Annex III to the Protocol stipulates the arbitration procedure as the only option for dispute settlement following the written consent of the PRC Government if China becomes a disputing party due to the interpretation and application of the Protocol (including those of Article 3, paragraphs 1 and 2). ${ }^{33}$

Third, China formulates reservations if the clauses provide both the ICJ and international arbitration as the only institution for dispute settlement. China has made such reservations to thirteen treaties. The Chinese government made a statement that China should not be bound by Article 17, paragraph 2 of the Convention on the Physical Protection of Nuclear Material, which provides for dispute settlement by both the ICJ and international arbitration institutions. ${ }^{34}$ China has also formulated a reservation to Article 16, paragraph 1 of the International Convention against the

32 Decision of the Standing Committee of the National People's Congress on Accession to the International Convention on the Elimination of All Forms of Racial Discrimination, Gazette of the State Council of the People's Republic of China, 1981, No. 25, at 783. < available only in Chinese>

33 Decision of the Standing Committee of the National People's Congress on Ratification of the Protocol of 1996 to the Convention on the Prevention of Marine Pollution by Dumping of Wastes and Other Matter, Gazette of the Standing Committee of the National People's Congress of the People's Republic of China, 2006, No. 6, at 41. <available only in Chinese>

34 Decision of the State Council on Accession to the Convention on the Physical Protection of Nuclear Material, Gazette of the State Council of the People's Republic of China, 1989, No. 23, at 850.<available only in Chinese> 
Taking of Hostages, ${ }^{35}$ which offers the ICJ and international arbitration as the only dispute settlement options for the parties. ${ }^{36}$

Fourth, China has made the only reservation to Article 66 of the VCLT, ${ }^{37}$ which provides:

If, under Paragraph 3 of Article 65, no solution has been reached within a period of 12 months following the date on which the objection was raised, the following procedures shall be followed: (a) any one of the parties to a dispute concerning the application or the interpretation of Article 53 or 64 may, by a written application, submit it to the International Court of Justice for a decision unless the parties by common consent agree to submit the dispute to arbitration; (b) any one of the parties to a dispute concerning the application or the interpretation of any of the other articles in part $\mathrm{V}$ of the present Convention may set in motion the procedure specified in the Annex to the Convention by submitting a request to that effect to the Secretary-General of the United Nations.

China formulated such reservations mainly because it has always advocated the settlement of disputes between States by means of negotiations and consultations. ${ }^{38}$ China holds the opinion that the State party concerned itself knows best the history and the status quo of the dispute. Therefore, negotiations and consultations are helpful not only to enhance the understanding of the States in disputes, but also to clarify facts, to resolve contradictions, as well as to avoid bringing deep disaster to the people of both sides. ${ }^{39}$ In practice, China has delimited the land boundary with 12 of 14 neighboring States through equal and friendly negotiations and consultations and successfully settled down the northern Gulf maritime boundary dispute with Vietnam. ${ }^{40}$ These State practices would have led China to resolve such a kind of

35 Decision of the Standing Committee of the National People's Congress on Accession to the International Convention against the Taking of Hostages, Gazette of the Supreme People's Court of the People's Republic of China, 1993, No.1, at 5. <available only in Chinese>

36 It reads: "Any dispute between two or more States Parties concerning the interpretation or application of this Convention which is not settled by negotiation shall, at the request of one of them, be submitted to arbitration. If within six months from the date of the request for arbitration the parties are unable to agree on the organization of the arbitration, any one of those parties may refer the dispute to the International Court of Justice by request in conformity with the Statute of the Court."

37 Decision of the Standing Committee of the National People's Congress on Ratification of the Vienna Convention on the Law of Treaty, Gazette of the Standing Committee of the National People's Congress of the People's Republic of China, 1997, No. 3, at 115. <available only in Chinese>

38 Tie-Ya Wang, International LaW [国际法] 609 (Beijing: Law Press, 1995).

39 Id.

40 Sheng Zhong, Negotiation is the only way to resolve the disputes [谈判协商是解决争议唯一出路], PEOPLE's DAILY, June 10, 2016, at A3. 
disputes through negotiations and consolations.

\section{B. Reservations to the Treaties Signed or Ratified by Taiwan Authorities}

Up until 1949, the former the Republic of China ("ROC") government had concluded treaties with foreign States. When it was driven to Taiwan in 1949, the PRC government has respectively recognized, repealed, amended or renewed the treaties acceded to by the ROC based on their contents. Between 1949 and 1971, the PRC did not yet regain a legitimate seat in the UN, but Taiwan's Authorities still signed, ratified, accepted, agreed with, or acceded to a number of multilateral treaties under the name of the 'Chinese' government. As Taiwan is not qualified to represent 'China' as a state in international law, its acts were illegal and invalid. By formulating such reservations, the PRC government reemphasized its adherence to the "One China Policy"

\section{The Reservations on the Non-application of the Treaties to the HKSAR or the MSAR}

China has formulated reservations to 19 treaties regarding to the HKSAR or the Macao Special Administrative Region ("MSAR"). When it acceded to the International Convention for the Protection of New Varieties of Plants 1978, China made a statement that the Convention would not apply to the HKSAR without the further notice from the Chinese government. ${ }^{41}$ On August 28, 2004, the 11th Meeting of the Standing Committee of the Tenth National People's Congress decided to ratify the Convention for the Safeguarding of the Intangible Cultural Heritage, which was adopted at the 32nd session of the General Assembly of UNESCO on November 3, 2003. At that time, the Committee also made a statement that the Convention would not apply to the HKSAR without the further notice from the Chinese government. ${ }^{42}$

The Chinese government has formulated such reservations on the solid legal basis. First, Article 153, paragraph 1 of the Basic Law of the HKSAR provides:

41 Decision of the Standing Committee of the National People's Congress on Accession to the International Convention for the Protection of New Varieties of Plants (1978), Gazette of the Standing Committee of the National People's Congress of the People's Republic of China, 1998, No. 4, at 25. <available only in Chinese>

42 Decision of the Standing Committee of the National People's Congress on Accession to the Convention for the Safeguarding of the Intangible Cultural Heritage, Gazette of the State Council of the People's Republic of China, 2005, No. 1, at 30. <available only in Chinese> 
The application to the Hong Kong Special Administrative Region of international agreements to which the People's Republic of China is or becomes a party shall be decided by the Central People's Government, in accordance with the circumstances and needs of the Region, and after seeking the views of the government of the Region.

Article 138, paragraph 1 of the Basic Law of the MSAR also provides:

The application to the Macao Special Administrative Region of international agreements to which the People's Republic of China is a member or becomes a party shall be decided by the Central People's Government, in accordance with the circumstances and needs of the Region, and after seeking the views of the government of the Region.

Accordingly, after seeking the views of the governments of the two Regions, the Central People's Government (Beijing) would formulate reservations for nonapplication of the treaties to the HKSAR or the MSAR following their views. Only in an exceptional case would a treaty have been extended to Hong Kong against its objections. $^{43}$

Second, Article 29 of the VCLT stipulates that: "Unless a different intention appears from the treaty or is otherwise established, a treaty is binding upon each Party in respect of its entire territory." Therefore, in principle, the treaty is binding upon the entire territory, while the State Party could make a reservation on the application of the treaty to parts of the territory. As pointed out by Taslim Elias, in practice, many treaties contain a special stipulation known as "territorial application clause." These various forms of "territorial application clauses" aim to limit the territorial scope of the application of treaties to parts of the territory. A State can limit the territorial scope of application by signing, ratifying or making reservations. ${ }^{44}$

Third, China's practice is also supported by GPRT which was adopted in 2011. GPRT 1.1.3 provides:

A unilateral statement by which a State purports to exclude the application of some provisions of a treaty, or of the treaty as a whole with respect to certain specific aspects, to a territory to which they would be applicable in the absence of such a statement constitutes a reservation.

43 Aust, supra note 31, at 190.

44 T. Elias, The Modern Law of Treaties 49-50 (1974). 


\section{D. "Statements of the Chinese Government on the Application of Reservations of the Treaties to the HKSAR"}

On the eve of the hand-over of Hong Kong on January 1, 1997, the State Council of China issued the "Statements and Reservations of the Chinese Government for the Application of the Multilateral Treaties to the HKSAR," which contains reservations and statements specifically for the continued application of 62 multilateral treaties to the HKSAR. ${ }^{45}$

There are broadly two different categories of treaties in this regard. The first category has been acceded to by mainland China and the HKSAR, while the second one has been acceded to only by the HKSAR but not mainland China.

\section{The first category}

There are 24 treaties in this category. After Hong Kong was returned to China, such practice declined sharply so as to leave only one single case. The SCNPC decided on February 28, 2001 on the ratification of the International Covenant on Economic, Social and Cultural Rights. In this course, the SCNPC made a statement:

The International Covenant on Economic, Social and Cultural Rights is applied to the HKSAR and the MSAR on the basis of a note dated 20 June 1997 and 2 December 1999 from the Permanent Representative of the People's Republic of China to the SecretaryGeneral of the United Nations. The International Covenant shall be implemented through the laws of the Special Administrative Region, in accordance with the Basic Law of the HKSAR and the Basic Law of the MSAR. ${ }^{46}$

The above practice is in full compliance with China's domestic law and international practice. Pursuant to Article 13 of the Basic Law of the HKSAR, the Central People's Government shall be responsible for the foreign affairs relating to the HKSAR, including applying reservations of the treaties to the Region. According to the international custom, when a country is extending its territory, subject to its terms, any reservation or declaration made on ratification will apply to the territory, unless otherwise specified in the notification to the depositary. In this case, additional or

45 Statement and Reservation of the Chinese Government on Application of Multilateral International Treaties to the Hong Kong Special Administrative Region, Gazette of the State Council of the People's Republic of China, 1997, No. 39, at 1702-18. <available only in Chinese>

46 Decision of the Standing Committee of the National People's Congress on Ratification of the International Covenant on Economic, Social and Cultural Rights, Gazette of the Standing Committee of the National People's Congress of the People's Republic of China, 2001, No. 12, at 40. <available only in Chinese> 
modified reservations and declarations may also be attached. ${ }^{47}$

\section{The second category}

There are 34 treaties in this category. Before the hand-over of Hong Kong to China, the British government had applied some treaties to Hong Kong. Although some of these treaties have not been acceded to by China, it is legal and reasonable for the Chinese government to formulate reservations to them on the following grounds. First, the Central People's Government has the right to exercise diplomatic sovereignty over the HKSAR by formulating the reservations to those treaties. Second, the practice not only satisfies the high degree of autonomy of the HKSAR, but also conforms to China's domestic law. Article 153 of the Basic Law of the HKSAR provides:

International agreements to which the People's Republic of China is not a party but which are implemented in Hong Kong may continue to be implemented in the Hong Kong Special Administrative Region. The Central People's Government shall, as necessary, authorize or assist the government of the Region to make appropriate arrangements for the application to the Region of other relevant international agreements.

\section{E. Further Analysis}

In the 1970s and the 1980s, China made reservations mainly to the international dispute settlement clauses of multilateral treaties and to those signed or ratified by Taiwan Authorities under the name of the 'Chinese' government. As to the former reservations, first, China clearly notified the UN Secretariat that the PRC government had never accepted the compulsory jurisdiction of the ICJ, made by the former ROC government on October 26, 1946. China has finally made reservations to all the dispute settlement clauses of the ICJ or international arbitration institutions. ${ }^{48}$ As to the latter reservations, since regaining the legitimate seat at the UN in 1971, the PRC government ratified or acceded a number of the treaties signed or ratified by Taiwan's Authorities under the name of the 'Chinese' government. These reservations were based on the "One China Policy.",

47 Aust, supra note 31, at 184.

48 WANG, supra note 38 , at 612.

49 See Guoqing Jiang, Several issues concerning the international law and the international treaties [国际法与国际条约 的几个问题], the 14th Legislative Affairs lecture of NPC Standing Committee, available at http://www.npc.gov.cn/ npc/xinwen/2000-04/29/content_1459914.htm (last visited on Oct. 3, 2017). 
After 1990, the above two kinds of reservations obviously declined. First, in 1989, the Chinese government declared that for the terms on the ICJ, China would formulate such reservations only to parts of the treaties in the future. The Chinese government pointed out that negotiation should still be applied in the events of international disputes concerning the crucial national interests of China. ${ }^{50}$

Generally, the Chinese government should not formulate the reservations to the professional and technical international conventions concerning economy, trade, science, technology, aviation, transportation, culture, etc. which China has signed, ratified or acceded. ${ }^{51}$ Therefore, the number of such reservations sharply declined.

Second, regarding the treaties signed or ratified by Taiwan's Authorities in China's name, China has newly negotiated and concluded them in the name of the PRC. Therefore, these reservations faded away.

At the end of the Twentieth century, the reservations were mainly made to the HKSAR related treaties because the Chinese government made statements of the reservations to 62 treaties on how to apply them unceasingly to the HKSAR, on January 1, 1997.

Beginning with the twenty-first century, China has mainly formulated the reservations to exclude the treaties' application to the HKSAR or the MSAR. After the hand-over of the HKSAR and the MSAR, the Central People's Government carefully studied the legal situations of the HKSAR and the MSAR and made prudent arrangements on whether the treaties could be applied to the above two regions.

\section{Two Specific Reservations that China Should Withdraw}

\section{A. China's Reservation to the Right of Innocent Passage of Warships under the UNCLOS}

The SCNPC ratified the 1982 United Nations Convention on the Law of the Sea ("UNCLOS") at its 19th meeting on May 15, 1996. It made the following statement:

The provision of the United Nations Convention on the Law of the Sea about the right of innocent passage does not impede the maritime countries from the right of requiring

50 WANG, supra note 38 , at 613.

51 Id. 
foreign warship to obtain the permission or the right of being informed according to their laws and regulations. ${ }^{52}$

Although the right of innocent passage provided in Article 17 of the UNCLOS applies to all ships, ${ }^{53}$ China has excluded the right of innocent passage of 'warships' of the Contracting States from entering China's territorial waters.

China's primary purpose of making this reservation was to safeguard national security. The 1958 statement by the Chinese government on territorial waters, the 1983 Law of China on Maritime Traffic Safety and the 1992 Law on China's Territorial Waters and their Contiguous Zone, all these legal measures regulate that: "Military vessels of foreign nationality may not enter into the territorial waters of the People's Republic of China without the approval of the Government of the People's Republic of China." 54

However, Article 309 of the UNCLOS provides that: "No reservations or exceptions may be made to this Convention unless expressly permitted by other Articles of this Convention." Since there are no other provisions of the UNCLOS that expressly permit a reservation, it is generally agreed that the UNCLOS prohibits all reservations. Would reservations then be possible even when the Convention prohibits reservations? If so, how about its legal effect? These issues have not been clearly resolved in the VCLT. As to the first question, GPRT (1.3.3) provides:

When a treaty prohibits reservations to all or certain of its provisions, a unilateral statement formulated in respect of those provisions by a State or an international organization shall be presumed not to constitute a reservation. Such a statement nevertheless constitutes a reservation if it purports to exclude or modify the legal effect of certain provisions of the treaty, or of the treaty as a whole with respect to certain specific aspects, in their application to its author.

As to the second question, GPRT (3.3.1) provides:

A reservation formulated notwithstanding a prohibition arising from the provisions

52 See Decision of the Standing Committee of the National People's Congress on Ratification of the United Nations Convention on the Law of the Sea [中华人民共和国全国人大常委会关于批准《联合国海洋法公约》的决定], available at http://www.npc.gov.cn/wxzl/gongbao/2000-12/16/content_5003571.htm (last visited on Oct. 3, 2017). $<$ available only in Chinese>

53 R. Churchill \& A. Lowe, The Law of the Sea 89 (3d. ed. 1999).

54 The Statement by the Chinese Government on Territorial Waters (1958), art. 3; Law of China on Maritime Traffic Safety (1983), art. 11(2); Law on China's Territorial Waters and their Contiguous Zone (1992), art. 6 (2). 
of the treaty or notwithstanding its incompatibility with the object and purpose of the treaty is impermissible, without there being any need to distinguish between the consequences of these grounds for non-permissibility.

China is arguably facing a great legal risk for the reservation to the provisions concerning "innocent passage of warships" under the UNCLOS. In addition, China's adherence to the reservation has been inconsistent with most of the States' practices. Nowadays, there are only few States that still require warships to get permission before entering their territorial waters, such as Iran, Yemen, Amen and China. ${ }^{55}$ As a result, China should withdraw this reservation.

\section{B. General Reservation Formulated by China to the Chicago Convention and Its Protocols}

On the eve of the return of Hong Kong to China in 1997, the Chinese Government has specifically made declarations and reservations to numerous multilateral treaties for their continued application in Hong Kong. One of them is a statement for a reservation to the Convention on International Civil Aviation (hereinafter Chicago Convention) and its series of protocols. The statement says: "The implementation of Chapter XVIII of the Convention should not prejudice the sovereignty of the People's Republic of China. ${ }^{, 56}$ A critical point at issue lies in Article 87 (Chapter 18) of the Chicago Convention which involves the national sovereignty. Article 87 provides:

\footnotetext{
Each Contracting State undertakes not to allow the operation of an airline of a Contracting State through the airspace above its territory if the Council has decided that the airline concerned is not conforming to a final decision rendered in accordance with the previous article.
}

Since the HKSAR is an indivisible part of the PRC, the operation of an airline through the airspace over Hong Kong should be in full conformity with China's domestic law. Should Article 87 be permitted without a reservation by China, the discretion to allow the operation of an airline through the airspace over Hong Kong would be given to "the Council of the Chicago Convention." Because the control of territorial air space

55 See UNCLOS Entry into Force Registration Status Text, available at http://treaties.un.org/doc/Publication/MTDSG/ Volume\%20II/Chapter\%20XXI/XXI-6.en.pdf (last visited on Oct. 3, 2017).

56 Statement and Reservation of the Chinese Government on Application of Multilateral International Treaties to the Hong Kong Special Administrative Region, Gazette of the State Council of the People's Republic of China, 1997, No. 39, at 1704. <available only in Chinese> 
is one of the important parts of State sovereignty, it is an infringement of China's sovereignty. Eventually, China formulated the above reservation.

The reservation was also formulated to Chapter 18 of the Chicago Convention as a whole. However, it is too general and vague to implement. GPRT (3.1.5.2) provides that: "A reservation shall be worded in such a way as to allow its meaning to be understood, in order to assess in particular its compatibility with the object and purpose of the treaty." If the phrasing is vague or general, it is hard to determine whether the phrase is consistent with the purpose of the treaty. The International Law Commission emphasizes "shall be worded." ${ }^{, 57}$ It means that it is not just a formal requirement, but a substantive one.

In accordance with the treaty law, although a State is free to make reservations, other States also have the right to make acceptance or objection to the reservation. ${ }^{58}$ Often, this is the case with a reservation invoking domestic law of a State without specifying the relevant provisions of the law. The reservation based on the domestic law is so ambiguous that it is impossible for other States Parties to take positions on it. In addition, as the purpose of reservation is to exclude or modify the legal effects of the provisions of the treaty, those reservations are only valid to the extent that they "exclude or modify the legal effect of the particular aspect of the treaty." general reservations would thus prevent the treaty from functioning effectively. Thus, the general reservation does not conform to the purpose of the reservation. As the European Human Rights Committee points out:

Reservations must be specific and transparent so that the persons under the jurisdiction of the Commission and the reserving State, as well as other States Parties, are able to make clear whether the reserving State undertakes or not the obligations of human rights. Therefore, reservations must not be general, and must be directed against a provision of the Convention so as to specify precisely the scope of its provisions. ${ }^{60}$

As a result, China should revise the reservation and specify it to certain clauses of

57 Report of the International Law Commission to the General Assembly, 66 U.N. GAOR, Supp. No. 10, reprinted in [2011] II Y.B. Int'l L. Comm'n 364, U.N. Doc. A/66/10/Add.1 P.364 (Apr. 26-June 3 \& July 4-Aug. 12, 2011), available at http://www.un.org/en/ga/search/view_doc.asp?symbol=A/66/10/Add.1 (last visited on Sept. 15, 2017).

58 GPRT 2.6.2, 2.8.1. See also VCLT art. 20.

59 GPRT 1.1:2. Paragraph 1 is to be interpreted as including reservations which purport to exclude or to modify the legal effect of certain provisions of a treaty, or of the treaty as a whole with respect to certain specific aspects, in their application to the State or to the international organization which formulates the reservation.

60 Human Rights Committee, 52nd Sess., General Comment No. 24, U.N. Doc. CCPR/C/21/Rev.1/Add.6 (Nov. 11, 1994), available at http://www.un.org/en/ga/search/view_doc.asp?symbol=CCPR/C/21/Rev.1/Add.6 (last visited on Oct. 3, 2017). 
Chapter 18 of the Chicago Convention and its protocols.

\section{Renovation of the Treaty Reservation System of China: Shortcomings and Suggestions}

\section{A. The Shortcomings}

First, China currently lacks domestic laws that specifically regulate reservations to the treaties. Although China abides by the VCLT (Articles 19-23) on the reservations to treaties, the Convention, both relatively general and simple, is primarily intended to regulate how the State formulates reservations at the international level. China's reservations to treaties at the domestic level should be stipulated by its own domestic law. As the treaty reservation practice is becoming more complicated, the vacancy of China's domestic law has brought some negative impact to its future practices on this aspect. $^{61}$

Second, since 1949, China has not yet thoroughly reviewed its reservations. It has often caused problems in relation to domestic law. As some reservations were formulated based on the domestic law of that time, these reservations would have lost their legal grounds in China when this domestic law is amended or abolished. Hence, China should withdraw them in time. On December 29, 2006 when China decided to join the "WIPO Performances and Phonograms Treaty," China formulated a reservation because the Treaty in 2001 conflicted with China's Copyright Law. Although China's Copyright Law was amended in 2010 and it has been fully connected with the Treaty, China still has not withdrawn the abovementioned reservation. Such non-applicable reservations should thus be withdrawn soon through a comprehensive review. GPRT also requires States Parties to review reservations on a regular basis and consider withdrawing some non-applicable reservations. $^{62}$

Third, China's practice of reservations to the treaties are generally simple, with

61 Liling Tan \& Chengzhi Cheng, The Procedural Law of China on Conclusion of Treaties should be revised as soon as possible, HANNAN DaILY, Mar. 14, 2008, at A3.

62 GPRT 2.5.3: It reads: "1. States or international organizations which have formulated one or more reservations to a treaty should undertake a periodic review of such reservations and consider withdrawing those which no longer serve their purpose. 2. In such a review, States and international organizations should pay special attention to the aim of preserving the integrity of multilateral treaties and, where relevant, consider the usefulness of retaining the reservations, particularly in relation to developments in their internal law since the reservations were formulated." 
regard to lacking withdrawal of reservations, accepting reservations formulated by other States, proposing objections to reservations, and withdrawing objections to reservations. As mentioned above, there are only two cases when China withdrew its reservations.

When receiving each reservation, the UN Secretary-General shall notify all the States that have been or are entitled to become parties to a Convention to express their attitudes towards reservations within a specified period at the same time. ${ }^{63}$ However, China has never expressed its attitude within that time. Specifically, China has neither accepted reservations formulated by other States, nor proposed objections to reservations formulated by other States, nor withdrawn objections to reservations by other States.

China has so far received many notices from the UN Secretary-General, but hardly addressed any comments. It shows that China has neither paid enough attention to the reservations formulated by other States, nor conducted indepth analysis and research on them, thereby losing the opportunity to form the countermeasures. In contrast, those countries like the US, the UK, France, and Germany have accumulated rich practical experiences in treaty reservations. ${ }^{64}$ Their experiences would give China much to learn.

Last, throughout the long history of reservation practice, China has not indicated the reasons why it formulates the reservations to treaties. However, GPRT (2.1.2) provides that a reservation should, to an extent possible, indicate the reasons why it is being formulated. Such non-indication to the reasons of formulating the reservations would not be conducive for China to make 'dialogues' with other States Parties on the acceptance of reservations.

\section{B. The Suggestions}

First, the Chinese government should make domestic legislation on reservations to treaties respecting reasonable provisions of GPRT. Although GPRT is neither a binding instrument, nor the basis of the Convention on Reservations to Treaties, ${ }^{65}$

63 Treaty Section of the Office of Legal Affairs of UN, Summary of Practice of the Secretary-General as Depositary of Multilateral Treaties, ST/LEG/7/Rev.1, available at http:/www.un.org/en/ga/search/view_doc.asp?symbol=ST/LEG/7/ Rev.1 (last visited on Oct. 3, 2017).

64 Un, Multilateral Treaties Deposited with the Secretary-General, vols. I-III, ST/LeG/Ser.e/26 (Apr. 1, 2009), available at https://treaties.un.org/doc/source/publications/MTDSG/2009/English-I.pdf (last visited on Oct. 3, 2017).

65 A. Pellet, Seventeenth Report on Reservation of Treaties, U.N. Doc. A/CN.4/647/Add.1 (June 6, 2011), at 16, ๆ 4, available at $\mathrm{http}$ ///legal.un.org/docs/?symbol=A/CN.4/647/Add.1 (last visited on Oct. 3, 2017). 
it would be a significant benchmark to guide law and practice in this area. ${ }^{66}$ The representatives of China participated in the whole enacting process of GPRT and made nine thematic speeches on the topic "treaty reservation, which have not only affirmed the reasonable parts of GPRT, but also pointed out its shortcomings." ${ }^{67}$ Recently, China is revising the Law on the Procedure for Concluding Treaties of 1990. It should take advantage of this opportunity to stipulate the contents of reservations to treaties to better regulate the practice of treaty reservations.

Second, China should thoroughly review the reservations formulated to 83 multilateral treaties and then divide them into three categories: (1) the continuing reservations; (2) the reservations requiring improvements; and (3) the reservations for withdrawals. Despite the large workload, a complete assessment of the existing reservations is indispensable for China to arrange all reservations to treaties formulated for nearly 70 years. The international and domestic environments have undergone tremendous changes in both law and politics, China needs a complete review and a re-evaluation of the necessity and coherence of reservations responding to the political and legal needs. The reservations to the treaties that 'Taiwan' authorities signed or ratified in the China's name should be continued, because this is important to uphold the "One China Policy." Furthermore, the reservations with regard to the dispute settlement only via the ICJ or international arbitration institutions could be considered to withdraw by the Chinese Government.

Third, if reservations are based on the domestic laws which have undergone tremendous changes, the Chinese government should withdraw them. The question of reservations in multilateral treaties would be solved entirely within the scope of the freedom of contract. ${ }^{68}$ Article 22, paragraph 1 of the VCLT provides:

Unless the treaty otherwise provides, a reservation may be withdrawn at any time and the consent of a State which has accepted the reservation is not required for its withdrawal.

In this regard, Russia's experience is worth studying. The Russian Federation has been gradually reviewing the reservations formulated during the former Soviet Union and has withdrawn the reservations to the 1944 Convention on the Elimination

66 J. Crawford, Brownlie's Principles of Public International Law 377 (8th ed. 2012).

67 See The statements by the representatives of China on the topic, 'Treaty reservation' in the whole enacting process of GPRT < available only in Chinese>, available at http://www.fmprc.gov.cn/ce/ceun/chn/zgylhg/flyty/ldlwjh /t40109.htm (last visited on Oct. 3, 2017).

68 Hao-pei Li, General Introduction on the Law of Treaties [条约法概论], 201(1987). 
of All Forms of Racial Discrimination, the 1966 Convention on the Elimination of All Forms of Racial Discrimination, the 1979 Convention on the Elimination of All Forms of Discrimination against Women, and the 1989 Convention on the Elimination of Torture. $^{69}$

Fourth, China should carefully analyze the reservations formulated by other States such as the US, the U.K., France, and Russia to important international conventions including the Convention on Economic, Social and Cultural Rights, the Vienna Convention on Diplomatic Relations, the Vienna Convention on Consular Relations, etc. Since China is also a State Party to the above-mentioned Conventions, the reservations formulated by those States may affect China's stance. Moreover, China should fully evaluate the impacts of these reservations, which can be divided into the following three categories of the reservations: (1) not affecting China's interests; (2) affecting China's interests to a certain extent; and (3) seriously affecting China's interests. China may ignore the reservations that are not affecting its interests. As for reservations affecting its interests to a certain extent, China needs to carefully study them and to put forward prudent countermeasures. Regarding the reservations that seriously affect China's interests, it should face them in an official manner. Objections to reservations are not interference in the internal affairs of the other side. Rather, they are the rights under treaty law to safeguard national interests. The VCLT and GPRT also confer the right to oppose the reservations formulated by other States. $^{70}$

Fifth, China should try to elaborate the reasons for the reservations. It would not increase the difficulty of the reservations, but rather lead China as a reserving Party, other States concerned, and international organizations or monitoring bodies to exercise their functions effectively. China, as a reserving Party, should not only explain and clarify the reasons for the reservations, but also provide information that contributes to evaluating the validity of the reservations for the other States Parties. It may also facilitate the assessment of the work of such entities which interpret or enforcing treaties and monitor treaty mechanism.

Moreover, indicating the reasons for the reservations would help China, international organizations, as well as supervising bodies (if such agency exists)

69 W. Butler, The Law of Treaties in Russia and the Commonwealth of Independent States: Text and Commentary 135 (2002).

70 VCLT art. 20(4)(b). It reads: "An objection by another contracting State to a reservation does not preclude the entry into force of the treaty as between the objecting and reserving States unless a contrary intention is definitely expressed by the objecting State." See also VCLT art. 22(2). It reads: "Unless the treaty otherwise provides, an objection to a reservation may be withdrawn at any time. GPRT 2.6.2: A State or an international organization may formulate an objection to a reservation irrespective of the permissibility of the reservation." 
achieve a fruitful dialogue. This will not only eliminate other States' suspicions on the validity of the reservations, but also deepen mutual understanding.

\section{Conclusion}

This research has reviewed the Chinese practice in treaty reservations for nearly 70 years and analyzed some critical issues of the practice. The reservations to treaties formulated by China, either procedural or substantial, are not only in full conformity with the VCLT, but also embodies the features of Chinese approaches. However, the current treaty reservation system of China has certain limitations because there are neither domestic laws which specifically regulate reservations, nor complete and thorough reviews. China should overcome such difficulties and improve its treaty reservation system following global reservation practice, the VCLT and GPRT. 
